MATEC Web of Conferences 40, 05005 (2016)

DOI: $10.1051 /$ matecconf/20164005005

(C) Owned by the authors, published by EDP Sciences, 2016

\title{
Research of Snow-Melt Process on a Heated Platform
}

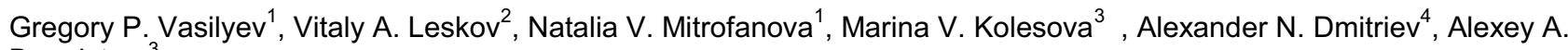 \\ Burmistrov $^{3}$ \\ ${ }^{1}$ JSC «NIIMosstroy», Moscow, Russia, 119192, Moscow, Vinnitskaya Street, house 8 \\ ${ }^{2} J S C$ «NIIMosstroy», Moscow, Russia, 119192, Moscow, Vinnitskaya Street, house 8 \\ ${ }^{3} J S C$ «Insolar-Energo», Moscow, Russia, 121433, Moscow, Filevskaya Street, house 32, building 3
}

${ }^{4}$ Department of Economics and Managing the City Construction, Engineering and Economic Faculty of the Russian Plekhanov Economic Academy, Russia, 115054, Moscow

\begin{abstract}
The article has shown the results of experimental researches of the snow-melt on a heated platform-near building heat-pump snow-melt platform. The near-building (yard) heat pump platforms for snow melt with the area up to $10-15 \mathrm{~m} 2$ are a basis of the new ideology of organization of the street cleaning of Moscow from snow in the winter period which supposes the creation in the megalopolis of the «distributed snow-melt system» (DSMS) using non-traditional energy sources. The results of natural experimental researches are presented for the estimation of efficiency of application in the climatic conditions of Moscow of heat pumps in the snow-melt systems. The researches were conducted on a model sample of the near-building heat-pump platform which uses the low-potential thermal energy ofatmospheric air. The conducted researches have confirmed experimentally in the natural conditions the possibility and efficiency of using of atmospheric air as a source of low-potential thermal energy for evaporation of the snow-melt heat pump systems in the climatic conditions of Moscow. The results of laboratory researches of snow-melt process on a heated horizontal platform are presented. The researches have revealed a considerable dependence of efficiency of the snow-melt process on its piling mode (form-building) and the organization of the process of its piling mode (form-building) and the organization of the process of its (snow mass) heat exchange with the surface of the heated platform. In the process of researches the effect of formation of an «ice dome» under the melting snow mass called by the fact that in case of the thickness of snow loaded on the platform more than $10 \mathrm{~cm}$ the water formed from the melting snow while the contact with the heating surface don't spread on it, but soaks into the snow, wets it due to capillary effect and freezes. The formation of «ice dome» leads to a sharp increase of snow-melt period and decreases the operating efficiency of the snow-melt platform as a whole.
\end{abstract}

\section{Introduction}

While cleaning and removal of snow from road and streets this purpose consumes about $40 \%$ of the total costs for winter maintenance of roads. These costs include not only the energy costs at the melting snow, but also the costs of moving snow mass for melting points. The Increase shoulder the transportation of snow for 10 miles at a cost comparable to the cost of fuel required to melt the same amount of snow [1]. The more efficient solution of this problem is in the were using for snow-melt of platforms energy distributed in the territory of a town (for example, disposed on court near-building territories) in which the snow melting takes place by non-traditional renewable energy sources (NTES), for example, the low-potential heat energy of atmospheric air, with application of heat pumps [2]. In the perspective, the heat pump snowmelt systems may be integrated into engineering systems and building designs. [3]. In the climatic conditions of Moscow, the most perspective for nearbuilding heat pump platforms of snow-melt is using as the low-potential source for evaporator the heat-pump equipment of the atmospheric air in combination with soil [4-5]. In this case, the efficiency of operation of near-building platforms of snow melt will be determined in many respects with the peculiarities of snow-melt process on the heated surface examined in this article. 


\section{Experimental researches}

The experimental researches of the snow-melt process were conducted on stand which imitates a heated plane horizontal surface. The stand was located in a climatic chamber in which the negative air temperature were held (see fig. 1)

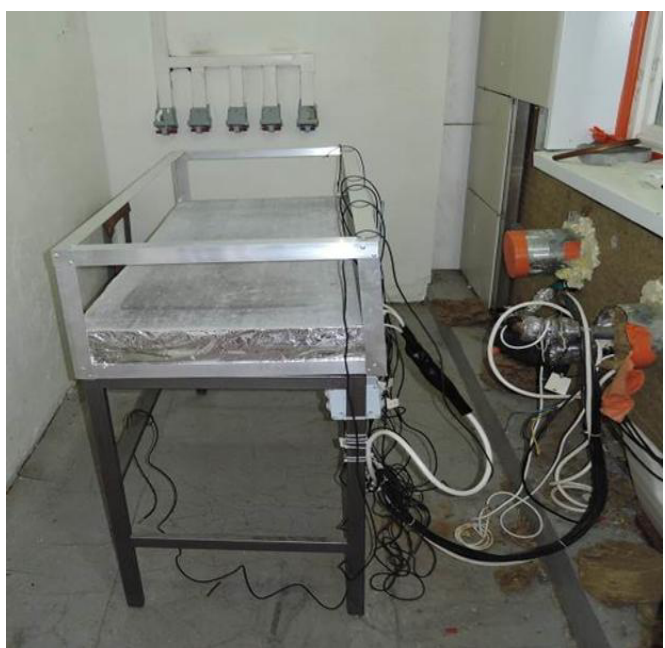

Figure 1. Appearance of the test stand placed in a climatic chamber

Fig.2. shows the placement of three heating circuits and four built-in surface temperature sensor. Heating cables provide three different heating zones - two on the edge surface and one Central part.

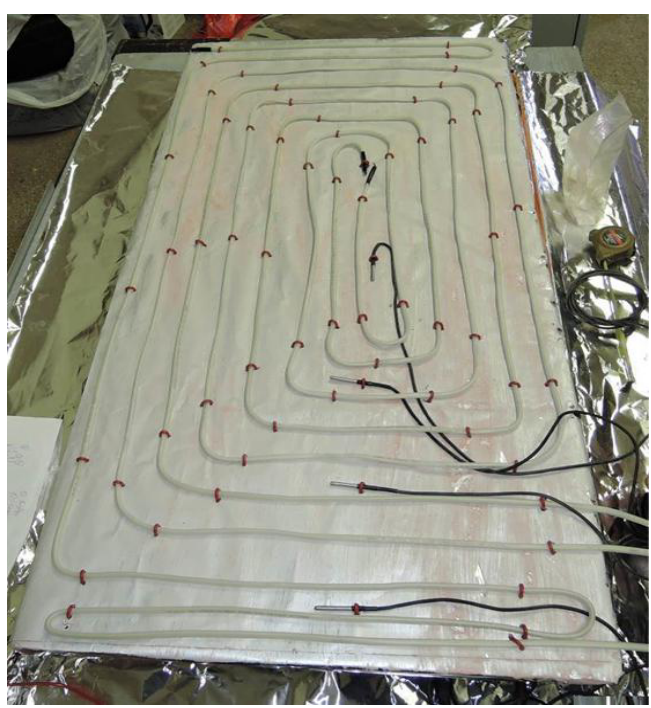

Figure 2. Accomodation of Heating Cables and Temperature Sensitive Elements on the Heated Surface

Before the realization of the research the mass and volume and then the density of the snow mass were determined. The snow density was $485 \mathrm{~kg} / \mathrm{m}^{3}$. In the procession of researches, the melting of the snow mass on the horizontal and inclined surface, at different temperatures of the atmospheric air. The main parameters of the experiments are shown in Table 1.

Table 1. Main parameters of the experiments

\begin{tabular}{|c|c|c|c|}
\hline \multirow{2}{*}{ Parameter name } & \multicolumn{3}{|l|}{ Value } \\
\hline & $\begin{array}{l}\text { Experim } \\
\text { ent } 1\end{array}$ & $\begin{array}{l}\text { Experime } \\
\text { nt } 2\end{array}$ & $\begin{array}{l}\text { Experim } \\
\text { ent } 3\end{array}$ \\
\hline $\begin{array}{c}\text { Atmospheric air } \\
\text { temperature } \mathrm{T} \\
\text { air, }{ }^{\circ} \mathrm{C}\end{array}$ & -10 & -5 & -10 \\
\hline $\begin{array}{c}\text { Heating surface } \\
\text { temperature } \mathrm{T} \\
\text { surface, }{ }^{\circ} \mathrm{C}\end{array}$ & +25 & +25 & +25 \\
\hline $\begin{array}{c}\text { Snow mass initial } \\
\text { temperature, } \mathrm{T} \\
\text { snow int., }{ }^{\circ} \mathrm{C} \\
\end{array}$ & -10 & -5 & -6 \\
\hline $\begin{array}{c}\text { The angle of } \\
\text { inclination of the } \\
\text { heating surface } \\
\text { from the } \\
\text { horizontal, } \varphi, \\
\text { deg. }\end{array}$ & 0 & 0 & 3 \\
\hline $\begin{array}{l}\text { Heating zone is } \\
\text { included }\end{array}$ & 3 & $1,2,3$ & 3 \\
\hline $\begin{array}{l}\text { The degree of } \\
\text { utilization of the } \\
\text { surface }\end{array}$ & Full & $\begin{array}{l}\text { In limits } \\
\text { of the } \\
\text { surface of } \\
\text { heating }\end{array}$ & \\
\hline
\end{tabular}

The object of the experimental 1 was studying of the process of snow-melt while the partial accommodation of the snow mass outside the limits of the horizontal heated surface of the platform. Such alocation is typical while piling of snow with the help mechanical means for example, of a mini tractor.

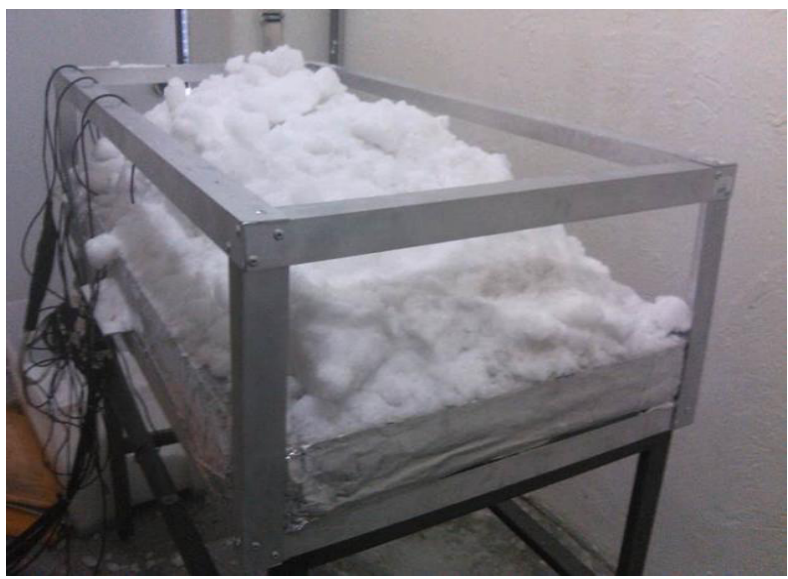

a) The initial loading on the stand with snow 


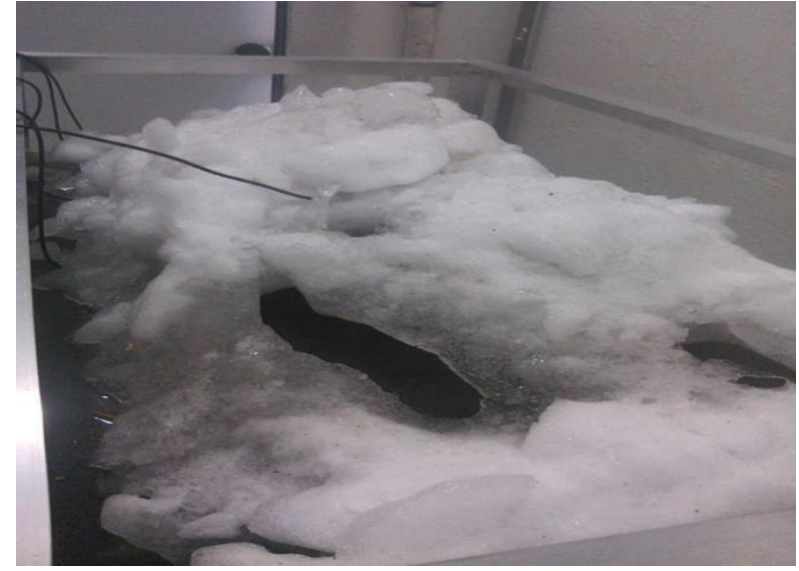

b) Snow mass in 25 hours

Figure 3. Stages of Snow-melt in Experiment 1

In 25 hours of the snow mass melt, a «snow dome» was formed (see Fig.3) what sharply reduced the heat exchange intensity and the snow-melt speed. In the future, it took an additional 2 days for complete removal from the surface of snow and ice masses.

In the process of experiment 2, (Fig. 3) the process of snow-melt was studied while the accomondation of the snow mass in the limits of the horizontal heated surface of the platform. Such an accommodation is typical while piling of snow with manual method.As the result of this experiment the complete removal of snow from the heating surface of the stand during a short period of time has become.

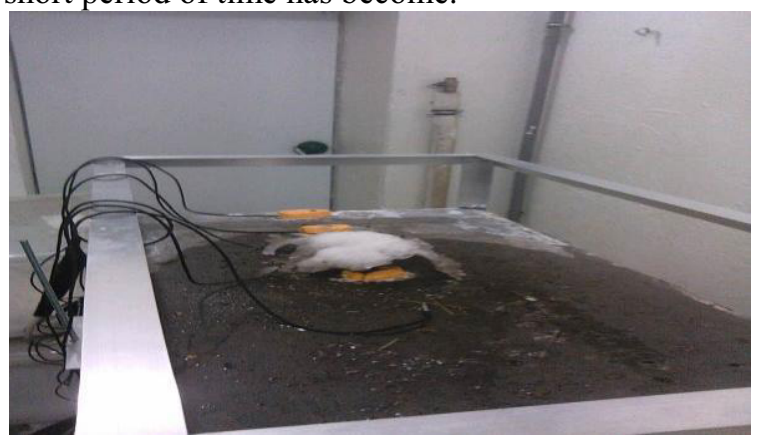

Figure 4. Experiment 2. The Process of Melting Snow

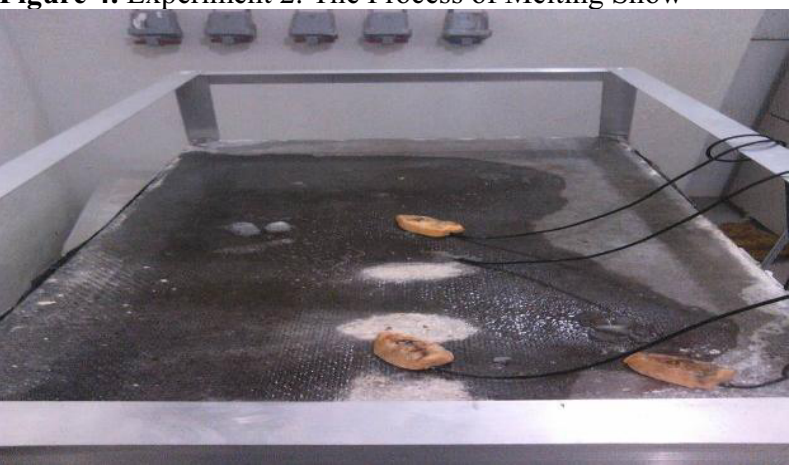

Figure 5. Experiment 3. The Snow has Melted
The object of experiment 3 (Fig. 4) was full of the snow-melt process while accommodation of the snow mass in a short period of time,since heating was carried out under the entire area is loaded on the stand the snow masses. The inclination angle of the surface from the horizontal was $3^{\circ} \mathrm{C}$. This arrangement snowpack is typical for sidewalks and inside the yard driveways, snow depth is $2 \mathrm{~cm}$. The results of experiment 3 was the total removal of melt water from heating the inclined surface of the stand for a short period of time because the heating was carried out under the entire area is loaded on the stand the snow masses.

\section{Conclusions}

The results of researches presented in the article revealed a significant dependence of the efficiency of the snow-mass melting process on its piling mode (formation) and organization of the process (snow mass) heat exchange with the surface of the heated platform. The experimental researches have shown the following: 1) the snow-mass melting on a horizontal heating surface takes place more intensively at the small loading thickness. When the loaded snow thickness is more than $10 \mathrm{cmthe}$ water formed from melting snow, in contact with the heating surface does not spread it, and soaks into the snow and wets it due to capillary effect. As a result an «ice dome» is formed.The «ice dome»gives rigidity to snow throughout the array, as a consequence, the contact with the heating surface decreases, and consequently decreases the efficiency of the system of snowmelt. 2)considerable influence on the process of thawing and melting of snow on a heated surface has the availability of soil inclusionsin the snow mass, such as rocks, large debris, etc.[5].

\section{Acknowledgement}

The Research was conducted by JSC "NIIMosstroy" with the financial support of the Ministry of Education and Science of Russia. Unique identifier of the project RFMEFI57914X0081.

\section{References}

1. Operating experience with geothermal heat-pump heat-supplying systems and the technical aspects of integrating them rationally in the energy balance of Russia Vasilyev G.P. Thermal Engineering. 2004. T. 51. № 6. C. 459-467.

2. Economically reasonable level of thermal protection of buildings Vasilyev G, P. The energy saving. 2002. No. 5. S. 48-51.

3. Results of field investigations of the thermal regime of the experimental energy-efficient homes. 
Vasilyev, P.Construction materials, equipment, technologies of XXI century. 2002. No. 6. C. 3.

4. Huajun Wang, Linbo Liu, Zhihao Chen. «Experimental investigation of hydronic snow melting process on the inclined pavement». Cold Regions Science and Technology 63 (2010) 44-49.

5. Takeuchi $\mathrm{M}$ et al. Development and numerical simulation of geothermal snow-melting method using foundation pile. Trans Soc Heating, AirConditioning and Sanitary Eng Jpn 1993; 52:5969. 